As-Syifaa Vol 09 (02) : Hal. 154-164, Desember 2017

ISSN : 2085-4714

\title{
UJI AKTIVITAS ANTIOKSIDAN EKSTRAK ETANOL DAUN ARBENAN (Duchesnea indica (Jacks.) Focke) DENGAN METODE DPPH
}

\author{
Nuraziza $^{1}$, Seniwati ${ }^{2}$, Risda Waris ${ }^{1}$ \\ ${ }^{1}$ Fakultas Farmasi Universitas Muslim Indonesia, Makassar \\ ${ }^{2}$ Fakultas Matematika Universitas Hasanuddin Makassar \\ Email: seniwatid@gmail.com
}

\begin{abstract}
Arbenan (Duchesnea indica (Jacks.) Focke) is a plant belonging to Rosaceae family which server as an antioxidant, flavonoids. This research aimed to determine the antioxidant activity of ethanol extract of arbenan leaves using DPPH. The leaves were extracted using maceration method with a sample size of 300 gs dissolved using ethanol $70 \%$, then obtained the viscous extract of 32,49 gs. The arrest of free radicals for each tested sample under the inhibition of DPPH. The tests were conducted at the 4 concentration series of 10,20,30, and 40 ppm by using methanol p.a by the addition of $0,5 \mathrm{~mL}$ with $3,5 \mathrm{~mL} \mathrm{DPPH}$ of $30 \mathrm{ppm}$. Antioxidant activity absorbance was measured by a spectrophotometer at the wavelength of $515 \mathrm{~nm}$ and $I C_{50}$ value was calculated based on the absorbance data. The calculations showed that the Arbenan leaves have a very strong antioxidant activity with $I C_{50}$ value of $30,20 \mu \mathrm{g} / \mathrm{mL}$.
\end{abstract}

Key words : Antioxidant, Ethanol extract of arbenan leaves Dunchesnea indica (Jacks) Focke, DPPH.

\section{PENDAHULUAN}

Indonesia merupakan negara kepulauan yang kaya akan berbagai bahan alam, salah satu sumber daya alam adalah tumbuh-tumbuhan. Dari bermacam-macam tumbuhan banyak di antaranya berkhasiat untuk obat. Jutaan penduduk di dunia menggunakan obat tradisional karena mereka mempercayainya dan kemudahan untuk mengakses tujuan terapeutik. Banyak obat-obatan modern dibuat dari tumbuhan obat, dan peracikannya dilakukan secara laboratoris klinis (telah diketahui dosis terapeutik melalui penelitian) ${ }^{1}$.

Salah satu tanaman yang dapat dimanfaatkan sebagai obat adalah tumbuhan (Duchesnea indica (Jacks) Focke yang dikenal dengan arbenan. Masyarakat memanfaatkan tumbuhan ini sebagai penurun panas, antiinfeksi dan stimulan ${ }^{2}$. Selain itu arbenan juga digunakan untuk pengobatan kanker, antiradang, menghentikan pendarahan, menghancurkan darah beku, dan mengurangi pembengkakan ${ }^{3}$. 
Uji aktivitas antioksidan ekstrak etanol daun Arbenan (Duchesnea indica (Jacks.) Focke) dengan metode DPPH

Seluruh bagian tanaman arbenan mengandung saponin, flavanoid, dan $\operatorname{tanin}^{2}$. Flavanoid merupakan senyawa yang memiliki aktivitas antioksidan yang disebabkan adanya gugus hidroksi pada struktur molekulnya sehingga disebut bioflavonoid. Begitu juga dengan beberapa tanin terbukti mempunyai aktivitas antioksidan, menghambat pertumbuhan tumor dan menghambat enzim seperti reverse transkiptase dan DNA topoisomerase. Sedangkan beberapa saponin bekerja sebagai antimikroba ${ }^{4}$.

Golongan senyawa flavanoid dapat diekstraksi dengan baik menggunakan etanol $70 \%{ }^{5}$. Keuntungan penggunaan pelarut etanol $70 \%$ adalah tidak beracun dan tidak berbahaya, digunakan etanol karena antioksidan yang hendak diekstrak diharapkan dapat diaplikasikan pada bahan makanan.

Antioksidan adalah senyawa yang dapat menghentikan reaksi propagasi radikal bebas, baik yang berasal dari produk samping metabolisme yang terjadi di dalam tubuh maupun yang berasal dari lingkungan seperti asap rokok, polusi udara, obat-obatan tertentu, sinar ultraviolet, dan radiasi ${ }^{6}$. Jumlah radikal bebas yang terus meningkat dalam tubuh dapat mengakibatkan terjadinya stres oksidatif sel. Jika hal ini terus menerus terjadi maka dapat memicu munculnya penyakit degeneratif seperti kanker, diabetes, peradangan dan kardiovaskuler ${ }^{7}$.

Berdasarkan uraian di atas, maka dilakukan penelitian tentang uji aktivitas antioksidan ekstrak etanol daun arbenan [Duchesnea indica (Jacks.) Focke] dengan menggunakan metode DPPH (1,1-Difenil-2pikrilhidrazil). Metode ini sering digunakan untuk mendeteksi kemampuan antiradikal suatu senyawa karena hasilnya terbukti akurat, reliabel, relatif cepat dan praktis. Metode penangkapan radikal DPPH memiliki kelebihan antara lain pereaksi tidak selektif sehingga senyawa dengan gugus fungsi dari antioksidan lemah pun dapat diidentifikasi dan waktu stabil setelah terjadi reaksi cukup memadai untuk di analisis ${ }^{8}$. Metode DPPH dapat digunakan pada pelarut organik berair maupun nonpolar, maka antioksidan hidrofilik maupun lipofilik dapat di uji aktifitasnya.

\section{METODE PENELITIAN}

\section{Alat dan Bahan Penelitian}

Alat-alat yang digunakan pada penelitian ini adalah blender, batang pengaduk, seperangkat alat maserasi, 
Uji aktivitas antioksidan ekstrak etanol daun Arbenan (Duchesnea indica (Jacks.) Focke) dengan metode DPPH

toples kaca, cawan porselin, gelas kimia $5 \mathrm{~mL}$ dan $100 \mathrm{ml}$ (pirex ${ }^{\circledR}$ ), labu tentukur $5 \mathrm{~mL} ; 10 \mathrm{~mL} ; 50 \mathrm{~mL} ; 100 \mathrm{~mL}$ (pirex ${ }^{\circledR}$ ), lampu UV254 dan UV366, pipet volume $1 \mathrm{~mL}, 2 \mathrm{~mL}, 5 \mathrm{~mL}, 10$ $\mathrm{mL}$, dan $20 \mathrm{~mL}$, rotary vacum evaporator ( $\mathrm{kka}^{\circledR} \mathrm{RV} 10$ basic), spektrofotometer ultraviolet visebel (simadzu UV 1800), tabung reaksi, timbangan analitik (ohaus) dan vortex.

Bahan-bahan yang digunakan dalam penelitian ini adalah daun Arbenan [Duchesnea indica (Jacks.) Focke], aquadest, DPPH (1,1Diphenyl-2-Picrylhydrazyl), kuersetin, etanol $70 \%, \mathrm{HCl}, \mathrm{NaOH}, \mathrm{FeCl}_{3}$, asam sulfat, dragendrof, kertas saring whattman, aluminium foil, lempeng KLT, metanol p.a, n-heksan dan etil asetat.

\section{Prosedur Penelitian}

Pengolahan Sampel

Sampel daun arbenan [Duchesnea indica (Jacks.) focke] yang telah dikumpulkan dibersihkan dari kotoran yang melekat pada daun menggunakan air mengalir lalu dikeringkan dengan cara dianginanginkan. Setelah kering sampel kemudian dihaluskan.

\section{Pembuatan Ekstrak Sampel}

Serbuk daun arbenan ditimbang sebanyak 300 gram dimasukan dalam wadah maserasi kemudian ditambahkan pelarut etanol $70 \%$ sebanyak $2700 \mathrm{~mL}$ sampai sampel terendam, kemudian dibiarkan selama 3-4 hari sambil diaduk berulang-ulang, selanjutnya dilakukan penyaringan dan diperoleh residu dan ekstrak etanol cair. Selanjutnya, ekstrak etanol cair yang telah diperoleh diuapkan dengan menggunakan alat Rotary Vacum Evaporator sehingga diperoleh ekstrak etanol kental.

\section{Identifikasi kandungan kimia}

Identifikasi Flavanoid

Sebanyak 0,5 gram ekstrak dilarutkan dengan $2 \mathrm{~mL}$ etanol $70 \%$ dan ditambahkan 3 tetes larutan $\mathrm{NaOH}$. Terjadinya perubahan intensitas warna kuning menjadi tidak berwarna pada penambahan asam sulfat mengindikasikan adanya senyawa flavanoid ${ }^{9}$.

\section{Identifikasi Fenol}

Sebanyak 0,5 gram ekstrak dilarutkan dengan $2 \mathrm{~mL}$ etanol $70 \%$ dan ditambahkan 3 tetes larutan $\mathrm{FeCl}_{3}$. Terbentuknya warna hitam kebiruan mengindikasikan adanya senyawa fenol ${ }^{9}$.

Uji aktivitas antioksidan secara kualitatif dengan metode Kromatografi Lapis Tipis (KLT)

Ekstrak etanol daun Arbenan ditotolkan pada lempeng KLT, kemudian dielusi dengan 
Uji aktivitas antioksidan ekstrak etanol daun Arbenan (Duchesnea indica (Jacks.) Focke) dengan metode DPPH

menggunakan eluen n-heksan : etil asetat (5:5), spot noda yang terelusi diamati pada beberapa penampak bercak yaitu sinar UV254 nm dan UV366 nm. Selanjutnya lempeng KLT disemprot dengan menggunakan DPPH dan diamati hingga terjadi perubahan warna dari ungu ke kuning, yang menunjukan ekstrak tersebut memiliki aktivitas antioksidan.

\section{Uji Aktivitas Antioksidan secara kuantitatif dengan metode DPPH}

Pengujian aktivitas antioksidan pada ekstrak etanol daun Arbenan [Duchesnea indica (Jacks.) Focke] dilakukan berdasarkan prosedur $^{10}$ dengan beberapa modifikasi.

\section{Pembuatan larutan DPPH}

Serbuk DPPH ditimbang sebanyak $10 \mathrm{mg}$ dilarutkan dengan $10 \mathrm{~mL}$ metanol p.a dalam labu tentukur untuk memperoleh larutan DPPH dengan konsentrasi 1000 ppm. Kemudian dipipet $3 \mathrm{~mL}$ lalu dicukupkan volumenya hingga $100 \mathrm{~mL}$ untuk memperoleh larutan DPPH dengan konsentrasi 30 ppm.

\section{Pengukuran daya antioksidan larutan blanko}

Larutan DPPH 30 ppm dipipet 4 $\mathrm{mL}$, kemudian larutan ini dibiarkan selama 30 menit pada suhu $37{ }^{\circ} \mathrm{C}$ pada ruangan gelap, kemudian diukur absorbansinya pada panjang gelombang $515 \mathrm{~nm}$ dengan menggunakan spektrofotometri UVVIS.

\section{Pengukuran daya antioksidan daun arbenan [Duchesnea indica (Jacks.) Focke]}

Larutan sampel 1000 ppm dibuat dengan melarutkan $10 \mathrm{mg}$ ekstrak daun arbenan [Duchesnea indica (Jacks.) Focke] dengan metanol p.a hingga $10 \mathrm{~mL}$ dalam labu tentukur. Dari larutan stok kemudian dipipet 1 $\mathrm{mL}$ lalu dicukupkan volumenya hingga $10 \mathrm{~mL}$ dalam labu tentukur untuk memperoleh larutan stok dengan konsentrasi 100 ppm. Kemudian dilakukan pengenceran dengan seri konsentrasi 10, 20, 30, dan 40 ppm, kemudian untuk konsentrasi $10 \mathrm{ppm}$ dipipet $0,5 \mathrm{~mL}$ dari larutan stok, konsentrasi $20 \mathrm{ppm}$ dipipet $1 \mathrm{~mL}$, konsentrasi $30 \mathrm{ppm}$ dipipet $1,5 \mathrm{~mL}$, dan konsentrasi $40 \mathrm{ppm}$ dipipet $2 \mathrm{~mL}$ kemudian masing-masing dicukupkan volumenya dengan metanol p.a hingga $5 \mathrm{~mL}$. Seri konsentarsi yang telah dibuat pengenceran kemudian akan dipipet $0,5 \mathrm{~mL}$ dimasukan dalam tabung reaksi dan masing-masing konsentrasi akan ditambahkan dengan larutan DPPH 30 ppm sebanyak 3,5 $\mathrm{mL}$. Kemudian campuran tersebut akan dihomogenkan dengan menggunakan alat vortex yang 
Uji aktivitas antioksidan ekstrak etanol daun Arbenan (Duchesnea indica (Jacks.) Focke) dengan metode DPPH

bertujuan untuk mencampurkan kedua larutan tersebut, kemudian diinkubasi pada suhu kamar $37{ }^{\circ} \mathrm{C}$ selama 30 menit, dan akan diukur absorbansinya pada panjang gelombang $515 \mathrm{~nm}$.

\section{Pengukuran daya antioksidan} sampel pembanding kuersetin

Larutan standar kuersetin 1000 ppm dibuat dengan melarutkan $10 \mathrm{mg}$ kuersetin dengan metanol p.a hingga $10 \mathrm{~mL}$ dalam labu tentukur. Dari larutan stok, kemudian dipipet $1 \mathrm{~mL}$ lalu dicukupkan volumenya hingga 10 $\mathrm{mL}$ dalam labu tentukur untuk memperoleh larutan stok dengan konsentrasi 100 ppm. Kemudian dilakukan pengenceran dengan seri konsentrasi 1 ppm, 2 ppm, 3 ppm, 4 ppm, dan 5 ppm dengan cara dipipet $0,05 \mathrm{~mL}, 0,1 \mathrm{~mL}, 0,15 \mathrm{~mL}, 0,2 \mathrm{~mL}$, dan $0,25 \mathrm{~mL}$ secara berurutan untuk masing-masing seri konsentrasi dan masing-masing konsentrasi dicukupkan volumenya dengan metanol p.a sampai volumenya $5 \mathrm{~mL}$. Seri konsentrasi yang telah dibuat masing-maing dipipet $0,5 \mathrm{~mL}$, lalu ditambahkan 3,5 mL DPPH 30 ppm. Kemudian larutan tersebut dihomogenkan dengan menggunakan alat vortex dan dibiarkan pada suhu kamar selama $37{ }^{\circ} \mathrm{C}$ selama 30 menit, lalu serapanya diukur pada panjang gelombang $515 \mathrm{~nm}$.

\section{Perhitungan IC50}

Persentase inhibisi radikal DPPH dihitung dengan rumus:

$\%$ inhibisi $=\frac{\mathrm{A}-\mathrm{B}}{\mathrm{A}} \times 100$

Dimana A adalah serapan blanko dan $B$ adalah serapan sampel. Nilai $I_{50}$ dihitung dengan menggunakan regresi persentase inhibisi ${ }^{11}$.

\section{HASIL PENELITIAN}

Tabel 1. Data persen (\%) rendemen ekstrak etanol $70 \%$ daun arbenan [Duchesnea indica (Jacks.) Focke]

\begin{tabular}{cccccc}
\hline $\begin{array}{c}\text { Nama } \\
\text { Sampel }\end{array}$ & $\begin{array}{c}\text { Jenis } \\
\text { Pelarut }\end{array}$ & $\begin{array}{c}\text { Berat Sampel } \\
\text { Segar }(\mathbf{g})\end{array}$ & $\begin{array}{c}\text { Berat Ekstrak } \\
(\mathbf{g})\end{array}$ & $\begin{array}{c}\text { Pelarut } \\
(\mathbf{L})\end{array}$ & $\begin{array}{c}\text { Rendemen } \\
\text { (\%) }\end{array}$ \\
\hline $\begin{array}{c}\text { Daun } \\
\text { Arbenan }\end{array}$ & $\begin{array}{c}\text { Etanol } \\
70 \%\end{array}$ & 300 & 32,49 & 2,700 & 10,83 \\
\hline
\end{tabular}


Uji aktivitas antioksidan ekstrak etanol daun Arbenan (Duchesnea indica (Jacks.) Focke) dengan metode DPPH

Tabel 2. Hasil penapisan fitokimia ekstrak etanol $70 \%$ daun arbenan [Duchesnea indica (Jacks.) Focke]

\begin{tabular}{ccccc}
\hline $\begin{array}{c}\text { Nama } \\
\text { sampel }\end{array}$ & $\begin{array}{c}\text { Pengujian } \\
\text { Senyawa }\end{array}$ & Reaksi yang Terjadi & Pustaka $^{9}$ & Hasil \\
\hline $\begin{array}{c}\text { Ekstrak } \\
\text { Etanol } 70 \\
\% \text { Daun } \\
\text { Arbenan }\end{array}$ & Flavanoid & $\begin{array}{c}\text { Terjadinya perubahan warna } \\
\text { kuning menjadi tidak } \\
\text { berwarna }\end{array}$ & $\begin{array}{c}\text { Terjadinya perubahan } \\
\text { warna kuning menjadi } \\
\text { tidak berwarna }\end{array}$ & + \\
\hline
\end{tabular}

Keterangan : $(+)=$ mengandung flavonoid dan fenol

Tabel 3. Hasil pengukuran absorbansi, persentase pengikatan $\mathrm{DPPH}$, dan nilai $\mathrm{IC}_{50}$ dari ekstrak etanol $70 \%$ daun arbenan [Duchesnea indica (Jacks.) Focke] dan pembanding kuersetin

\begin{tabular}{ccccc}
\hline Sampel & Konsentrasi (ppm) & Absorbansi & $\begin{array}{c}\text { Inhibisi } \\
(\%)\end{array}$ & $\begin{array}{c}\text { IC50 } \\
(\boldsymbol{\mu g} / \mathbf{m L})\end{array}$ \\
\hline Blanko & & & \\
Ekstrak & 10 & 0,793 & & \\
Etanol 70\% & 20 & 0,560 & 29,382 & \\
Daun Arbenan & 30 & 0,490 & 38,209 & 30,20 \\
\hline \multirow{2}{*}{ Kuersetin } & 40 & 0,395 & 50,189 & \\
& 1 & 0,314 & 60,403 & \\
& 2 & 0,645 & 18,663 & \\
& 3 & 0,624 & 21,437 & \multirow{2}{*}{0,97} \\
\hline
\end{tabular}

\section{PEMBAHASAN}

Pada penelitian ini

menggunakan sampel daun arbenan [Duchesnea indica (Jacks.) Focke] yang diambil dari gunung Bawakaraeng, Kabupaten Gowa, Sulawesi-selatan. Dalam penelitian ini dilakukan ekstraksi dengan menggunakan metode maserasi.

Metode maserasi dipilih karena prosesnya mudah dan tidak menggunakan suhu tinggi yang memungkinkan dapat merusak senyawa-senyawa kimia yang memiliki aktivitas antioksidan yang terdapat dalam sampel ${ }^{12}$. Proses maserasi sampel daun Arbenan Duchesnea indica (Jacks.) Focke] dilakukan dengan menggunakan pelarut etanol $70 \%$ sebanyak 2,700 L.

Hasil penapisan fitokimia yang dilakukan pada ekstrak etanol $70 \%$ daun arbenan [Duchesnea indica (Jacks.) Focke] menunjukkan adanya kandungan senyawa metabolit sekunder diantaranya flavanoid dan 
Uji aktivitas antioksidan ekstrak etanol daun Arbenan (Duchesnea indica (Jacks.) Focke) dengan metode DPPH

fenolik. Umumnya metabolit sekunder yang diperoleh bersifat polar sehingga tersari didalam pelarut polar yang digunakan yaitu etanol $70 \%$. Golongan senyawa flavanoid dapat diekstraksi dengan baik menggunakan etanol $70 \%{ }^{5}$. Setelah diperoleh ekstrak cair dari proses maserasi, dilakukan penguapan dan menghasilkan ekstrak kental sebanyak 32,49 gram. Dari ekstrak kental yang diperoleh kemudian dihitung persen rendemen yaitu sebesar 10,83\%. Penentuan rendemen berfungsi untuk mengetahui kadar metabolit sekunder yang terbawa oleh pelarut tersebut namun tidak dapat menentukan jenis senyawa yang terbawa ${ }^{13}$. Pengujian kualitatif antioksidan terlebih dahulu dilakukan elusi dengan kombinasi eluen. Kombinasi eluen yang cukup baik untuk mengelusi etanol $70 \%$ daun Arbenan [Duchesnea indica (Jacks.) Focke] yaitu pelarut $n$-heksan dan etil asetat dengan perbandingan 5:5. Setelah dielusi, dilakukan pengamatan dengan melihat noda pada sinar lampu $U_{254}$ dan $U V_{366} \mathrm{~nm}$, yang akan menghasilkan latar belakang (lempeng) menjadi gelap sehingga noda dapat berflourosensi dan dapat terlihat secara visual.

Setelah itu, dilakukan penyemprotan dengan menggunakan pereaksi DPPH. Adanya perubahan warna DPPH yang disemprotkan pada bercak plat KLT dari ungu menjadi kuning menandakan bahwa ekstrak etanol $70 \%$ daun Arbenan [Duchesnea indica (Jacks.) Focke] memiliki aktivitas antioksidan. Terbentuknya bercak kuning setelah penyemprotan DPPH disebabkan oleh adanya senyawa yang dapat mendonorkan atom hidrogen di dalam ekstrak sehingga molekul DPPH tereduksi yang diikuti dengan perubahan warna ungu dari larutan DPPH menjadi kuning bening.

Uji kuantitatif aktivitas antioksidan pada penelitian ini dilakukan dengan menggunakan metode DPPH (2,2-difenil-1pikrilhidrazil). Metode DPPH ini dipilih karena merupakan metode yang sederhana, mudah cepat dan peka serta hanya memerlukan sedikit sampel untuk evaluasi aktivitas antioksidan dari senyawa bahan alam $^{16}$. Prinsip pengukuran aktivitas antioksidan secara kuantitatif menggunakan metode DPPH ini adalah adanya perubahan intensitas warna ungu DPPH yang sebanding dengan konsentrasi larutan DPPH tersebut. Radikal bebas DPPH yang memiliki elektron tidak berpasangan akan memberikan warna ungu. Warna 
Uji aktivitas antioksidan ekstrak etanol daun Arbenan (Duchesnea indica (Jacks.) Focke) dengan metode DPPH

akan berubah menjadi kuning saat elektronnya berpasangan. Perubahan intensitas warna ungu ini terjadi karena adanya peredaman radikal bebas yang dihasilkan oleh bereaksinya molekul DPPH dengan atom hidrogen yang dilepaskan oleh molekul senyawa sampel sehingga terbentuk senyawa Difenil pikril hidrazil dan menyebabkan terjadinya peluruhan warna DPPH dari ungu ke kuning. Perubahan warna ini akan memberikan perubahan absorbansi pada panjang gelombang maksimum DPPH menggunakan spektrofotometri UV-Vis sehingga akan diketahui nilai aktivitas peredaman radikal bebas yang dinyatakan dengan nilai $I_{50}$

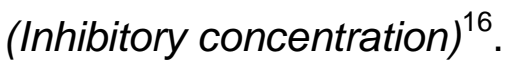

Pengukuran absorbansi ekstrak dengan DPPH menggunakan spektrofotometer UV-Vis yang sebelumnya dilakukan penentuan panjang gelombang maksimum DPPH. Panjang gelombang maksimum DPPH yang digunakan berada pada panjang gelombang $515 \mathrm{~nm}$. Panjang gelombang maksimum ini memberikan serapan paling maksimal dari larutan uji dan memberikan kepekaan paling besar ${ }^{16}$.

Selanjutnya, besarnya aktivitas antioksidan dari ekstrak dan kontrol positif yang digunakan diukur pada panjang gelombang $515 \mathrm{~nm}$ dengan volume sampel yang digunakan adalah $0,5 \mathrm{~mL}$ dan DPPH $3,5 \mathrm{~mL}$. Dimana konsentrasi sampel yang digunakan adalah 10, 20, 30, dan 40 ppm sedangkan konsentrasi pembanding adalah 1, 2, 3, 4, dan 5 ppm. Selanjutnya persamaan regresi yang diperoleh dari grafik hubungan antara konsentrasi sampel dan pembanding dengan persen penghambatan DPPH digunakan untuk mencari nilai $I_{50}$. Besarnya aktivitas antioksidan ditandai dengan nilai $I_{50}$, yaitu konsentrasi larutan sampel yang dibutuhkan untuk menghambat $50 \%$ radikal bebas $\mathrm{DPPH}^{16}$.

Pada penelitian ini diperoleh nilai $\mathrm{IC}_{50}$ dari sampel ekstrak etanol 70 $\%$ daun Arbenan sebesar 30,20 $\mu \mathrm{g} / \mathrm{mL}$, sedangkan nilai $\mathrm{IC}_{50}$ dari kuersetin sebesar $14,97 \mu \mathrm{g} / \mathrm{mL}$. Suatu senyawa dikatakan memiliki aktivitas antioksidan sangat kuat apabila nilai $\mathrm{IC}_{50}<50 \mu \mathrm{g} / \mathrm{mL}$, kuat apabila nilai $\mathrm{IC}_{50}$ antara $50-100 \mu \mathrm{g} / \mathrm{mL}$, sedang apabila nilai $I_{50}$ berkisar antara 101-150 $\mu \mathrm{g} / \mathrm{mL}$, dan lemah apabila nilai $\mathrm{IC}_{50}>$ $150 \mu \mathrm{g} / \mathrm{mL}$. Dari hasil penelitian dapat dikatakan bahwa ekstrak etanol $70 \%$ daun Arbenan berpotensi sebagai zat antioksidan dan memiliki aktivitas antioksidan yang sangat kuat. 
Uji aktivitas antioksidan ekstrak etanol daun Arbenan (Duchesnea indica (Jacks.) Focke) dengan metode DPPH

Potensi aktivitas antioksidan masing-masing sampel dapat dilihat dari nilai $I_{50}$. Nilai $I_{50}$ berbanding terbalik dengan kemampuan senyawa menangkap radikal bebas DPPH, semakin kecil nilai $\mathrm{IC}_{50}$ maka semakin besar kemampuan senyawa untuk menangkap radikal bebas. Nilai $I_{50}$ ekstrak etanol $70 \%$ daun Arbenan > kuersetin yang berarti bahwa kemampuan aktivitas penangkapan radikal bebas yang paling besar adalah kuersetin. Hal ini disebabkan kuersetin memiliki beberapa gugus hidroksi fenolik yang dapat membentuk radikal baru ${ }^{17}$

Berdasarkan hasil skrining fitokimia didapat golongan senyawa yang berpotensi sebagai antioksidan di dalam ekstrak etanol $70 \%$ daun Arbenan diantaranya adalah flavanoid dan fenol. Senyawa fenolik dan flavanoid pada strukturnya mengandung gugus hidroksil yang dapat mendonorkan atom hidrogennya kepada radikal bebas, sehingga senyawa fenolik dan flavanoid berpotensi sebagai antioksidan ${ }^{14}$.

Flavanoid merupakan senyawa polifenol yang mempunyai kemampuan untuk menyumbangkan atom hidrogen kepada senyawa radikal bebas, maka aktivitas antioksidan senyawa polifenol dapat dihasilkan pada reaksi netralisasi radikal bebas atau pada penghentian reaksi berantai yang terjadi. Adapun senyawa fenol mempunyai kemampuan untuk menyumbangkan atom hidrogen, sehingga radikal DPPH dapat tereduksi menjadi bentuk yang lebih stabil. aktivitas peredaman radikal bebas senyawa fenol dipengaruhi oleh jumlah dan posisi hidrogen fenolik dalam molekulnya. Semakin banyak jumlah gugus hidroksil yang dimiliki oleh senyawa fenol maka semakin besar aktivitas antioksidan yang dihasilkan ${ }^{18}$.

\section{KESIMPULAN}

Berdasarkan hasil penelitian yang telah dilakukan dapat disimpulkan bahwa ekstrak etanol 70 $\%$ daun arbenan [Duchesnea indica (Jacks.) Focke] berpotensi sebagai zat antioksidan dengan kategori aktivitas antioksidan yang sangat kuat. Nilai $\mathrm{IC}_{50}$ ekstrak etanol $70 \%$ daun arbenan [Duchesnea indica (Jacks.) Focke] sebesar 30,20 $\mu \mathrm{g} / \mathrm{mL}$, sedangkan kuersetin memiliki nilai $I_{50}$ sebesar $14,97 \mu \mathrm{g} / \mathrm{mL}$.

\section{DAFTAR PUSTAKA}

1. Chaudury RR. Herbal Medicine for Human Health. , New Delhi : World Health Organization; 1992.

2. Hutapea JR. Inventaris Tanaman Obat Indonesia. Balai Penerbitan 
Uji aktivitas antioksidan ekstrak etanol daun Arbenan (Duchesnea indica (Jacks.) Focke) dengan metode DPPH

dan Pengembangan Kesehatan; 1991.

3. Dalimartha S. Atlas Tumbuhan Obat Indonesia, Jilid 3. Jakarta: Puspaswara; 2004.

4. Artanti N, Jamilah dan Hartati S. Laporan Teknis Sub Tolok Ukur Pengembangan Senyawa Potensial antikanker dari Taxus sumatrana dan Benalu. Serpong : Puslit Kimia LIPI; 2003.

5. Harborne JB. Metode Fitokimia 5 Penuntun cara modern menganalisa tumbuhan. Terbitan Kedua. Terjemahan Kosasih Padmawinata dan Iwang Soediro. Bandung: ITB; 1987.

6. Arief S. Radikal Bebas, Laporan Penelitian, IImu Kesehatan Anak, Surabaya: Fakultas Kedokteran UNAIR; 2008.

7. Wijeratne SSK, Cuppett SL, Schlegel V. Hydrogen Peroxide Induced Oxidative Stress Damage and Antioxidant Enzyme Response in Caco-Human colon cells. Journal Agricultural and Food Chemistry 2005;53:8768-8774.

8. Deng, Wangyuan, Guangzhong. A novel antioxidant activity index $(A A U)$ for natural products using the DPPH assay. Food Chemistry 2011;125:1430-1435.

9. Tiwari, Kumar, Kaur Mandeep, Kaur Gurpreet \& Kaur Harleem. Phytochemical Screening and Extraction: $A$ Review. Internationale Pharmaceutica Sciencia 2011;1(1).

10.Brand-Williams W, Cuvelier ME and Berset $\mathrm{C}$. Use of a free radical method to evaluate antioxidant activity.

Lebensmitted-

Wissenschaft und-

Technologie/Food Science and

Technology; 1995.

11. Ahmad AR, Mun'im A and Elya B. Study of antioxidant activity With reduction of free radikal DPPH and Xanthine Oxidase inhibitor of the extract Ruella tuberosa linn lear. Internasional Research joernal of pharmacy 2012;102:29 47,48.

12. Pratiwi D, Wahdaningsih $\mathrm{S}$, Isnindar. Uji Aktivitas Antioksidan Daun Bawang Mekah (Eleutherine Americana Merr.) dengan Metode $D P P H$. Trad. Med. Journal 2013;18(1).

13. Ukieyanna E. Aktivitas Antioksidan, Kadar Fenolik, dan Flavonoid Total Tumbuhan Suruhan (Peperomia pellucid L. Kunth). Bogor : Fakultas Teknologi Pertanian Institut Pertanian Bogor; 2012.

14. Molyneux P. The Use of The Stable Free Radical

Diphenylpicrylhydrazyl (DPPH) for Estimating Antioxidant Activity. Songklanakarin. $J$ Sci Technol 2004;26(2):212.

15. Andayani R, Yovita L, Maimunah. Penentuan aktivitas antioksidan, kadar fenolat total dan likopen pada buah Tomat (Solanum lycopersicum I). J Sains dan Teknologi Farmasi 2008;13(1): 3137.

16. Nic'iforovic' $\mathrm{N}$, et al. Antioxidant Activity of Selected Plant Species; Potential New Sources of Natural Antioxidants, Food and Chemical Toxicology 2010;48:3125-3130. 
Uji aktivitas antioksidan ekstrak etanol daun Arbenan (Duchesnea indica (Jacks.) Focke) dengan metode DPPH

17. Ridho EA. Uji Aktivitas Antioksidan Ekstrak Metanol Buah Lakum (Cayratia trifolia) Dengan Metode Dpph (2,2-Difenil-1-Pikrilhidrazil).
Pontianak: Fakultas Kedokteran Universitas Tanjungpura; 2013.

18. Es-Safi NE, S. Ghidouche $\mathrm{PH}$. Ducrot, Molecule 12 (2007) 2228. 